\title{
HUBUNGAN PEMAHAMAN KONSEP DASAR KIMIA DENGAN KEMAMPUAN LITERASI SAINS MAHASISWA
}

\author{
Seprianto \\ Program Studi Pendidikan Kimia, FKIP Universitas Samudra \\ Jln. Kampus Meurandeh, Langsa - Aceh 24416 \\ Email: seprianto_kimia@unsam.ac.id
}

\begin{abstract}
Abstrak
Penelitian ini bertujuan menentukan hubungan pemahaman konsep dasar kimia dengan kemampuan literasi sains. Penelitian merupakan penelitian kuantitatif dengan metode survei. Teknik pengambilan sampel secara purposive sampling. Sampel merupakan 149 mahasiswa pendidikan kimia dari beberapa kelas dan angkatan. Instrumen pengumpul data terdiri atas tes pemahaman konsep dasar kimia dan tes literasi sains. Data dianalisis dengan uji korelasi Spearman Rank pada program SPSS. Dari analisis data didapatkan koefisien korelasi 0,534 atau lebih besar dari $r_{\mathrm{s}}$ tabel pada taraf signifikansi 5\% yaitu 0,197. Sementara itu, signifikansi atau nilai probabilitasnya sebesar 0,000 atau lebih kecil dari 0,05 sehingga disimpulkan ada hubungan yang signifikan antara pemahaman konsep dasar kimia dengan kemampuan literasi sains. Jadi semakin tinggi pemahaman konsep dasar kimia mahasiswa maka kemampuan literasi sainsnya juga semakin tinggi.
\end{abstract}

Kata kunci: hubungan, pemahaman konsep, literasi sains.

\begin{abstract}
This study aims to determine the correlation of understanding the basic concepts of chemistry with scientific literacy ability. This research is quantitative research with survey method. The sampling technique was purposive sampling. The sample was 149 chemistry education students from several classes. Data collection instruments consist of tests of understanding the basic concepts of chemistry and scientific literacy tests. Data were analyzed with Spearman Rank correlation test in the SPSS program. From the analysis of the data obtained a correlation coefficient of 0.534 or higher than the $r_{s}$ table at the 5\% significance level is 0.197. Meanwhile, significance or probability value is 0.000 or lower than 0.05 so it was concluded that there was a significant correlation between understanding the basic concepts of chemistry with the scientific literacy ability. So the higher the understanding basic concepts of chemistry, the higher the scientific literacy ability.
\end{abstract}

Keywords: correlation, concept understanding, scientific literacy.

PENDAHULUAN

Di abad ke-21, literasi sains menjadi salah satu kemampuan yang dibutuhkan. Peran dan kegunaan sosial pengetahuan sains merupakan perspektif literasi sains (Holbrook dan Rannikmae,
2009). OECD merumuskan literasi sains sebagai kompetensi dalam memanfaatkan pengetahuan sains, merumuskan pertanyaan, dan mengambil kesimpulan berdasarkan bukti sains (OECD, 1999). Selain itu OECD juga menyatakan literasi 
sains sebagai kapasitas berpartisipasi dengan isu-isu dan ide-ide sains, sebagai masyarakat yang reflektif (OECD, 2019). Literasi kimia merupakan bagian dari literasi sains (Cidgemoglu, et al., 2017).

$$
\text { Literasi sains mencakup }
$$
kompetensi mengenali isu sains, mengeksplanasi fenomena dengan sains dan memanfaatkan bukti sains (OECD, 2013). Sementara itu menurut OECD (2019) literasi sains terdiri atas tiga kompetensi: mengeksplanasi fenomena dengan sains, merancang dan mengevaluasi pertanyaan ilmiah, dan menginterpretasi data secara saintifik.

Shwartz et al. (2006), menyatakan PISA dan TIMSS sebagai studi paling representative dalam mengukur literasi sains. Setiap tiga tahun, OECD menyelenggarakan studi PISA. Indonesia selalu berpartisipasi dalam studi PISA dari tahun 2000 sampai 2018, meskipun bukan negara anggota OECD. Melalui studi PISA, didapatkan gambaran keunggulan dan kekurangan pelajar Indonesia di bidang sains, matematika, dan membaca sehingga menjadi bahan pertimbangan dalam perumusan kebijakan di bidang pendidikan (Balitbang Depdiknas, 2007). Sementara itu, TIMSS merupakan studi empat tahunan oleh IEA bidang matematika dan sains. Indonesia telah ikut serta dalam studi TIMSS dari tahun 1999 sampai 2015.

Meskipun Indonesia selalu berpartisipasi dalam PISA secara konsisten, namun siswa Indonesia literasi sainsnya selalu di bawah rerata OECD. Dari studi PISA 2018, siswa Indonesia literasi sainsnya hanya diperingkat 70 dari 78 negara peserta dengan rata-rata skor 396 (OECD, 2019), menurun dari hasil studi tahun 2015 yang diperingkat 62 dari 70 negara partisipan dengan skor rerata 403 (OECD, 2018). Sementara itu, Diana, et al. (2015) memperkuat bukti bahwa literasi sains yang dimiliki siswa pada ranah kognitif termasuk sangat kurang.

Sebagai calon pendidik generasi masa depan, mahasiswa prodi pendidikan kimia harus unggul kemampuan literasi sainsnya. sehingga dapat membentuk peserta didik menjadi SDM yang berdaya saing. Sujana et al. (2014) dalam penelitiannya menemukan bahwa pencapaian literasi sains hanya dimiliki setengah dari total mahasiswa dan kurang dari sepertiga guru. Hasil penelitian Fakhriyah et al. (2017) dan Rubini et al. (2016) juga menunjukkan rendahnya tingkat literasi sains guru ataupun mahasiswa bidang sains di Indonesia.

Berbagai faktor yang berkorelasi dengan literasi sains telah diselidiki oleh 
sejumlah penelitian. El Islami, et al. (2015) menyatakan tidak menemukan hubungan berarti diantara kepercayaan diri siswa dan kemampuan literasi sainsnya. Demikian juga dengan hasil penelitian Sukowati, et al. (2017) dimana hubungan kemampuan literasi sains dengan metakognitif sangat lemah. Sementara itu, Susiati, et al. (2018) menyimpulkan bahwa terdapat kontribusi HOTs pada kemampuan literasi sains. Sejalan dengan itu, Rahayuni (2016) menemukan kuatnya korelasi literasi sains dan keterampilan berpikir kritis. Kemampuan berpikir kreatif dan sikap terhadap sains diketahui memilki korelasi positif dengan literasi sains (Rusdi et al., 2017). Namun, sejauh ini belum ada penelitian untuk melihat hubungan antara pemahaman konsep dasar kimia dan kemampuan literasi sains. Penelitian ini memiliki sasaran mengetahui keeratan hubungan pemahaman konsep dasar kimia dan kemampuan literasi sains.

\section{METODE}

Metode survei digunakan dalam penelitian kuantitatif ini. Populasi penelitian merupakan mahasiswa dari beberapa universitas di wilayah Aceh yang memiliki prodi pendidikan kimia. Teknik pengambilan sampel secara purposive sampling. Sampel merupakan 149 mahasiswa pendidikan kimia dari berbagai kelas dan angkatan. Instrumen pengumpul data terdiri atas tes pemahaman konsep dasar kimia dan tes literasi sains. Soal-soal tes pemahaman konsep dasar kimia diambil dari soal-soal TIMSS. Sementara itu soal-soal tes literasi sains diambil dari soal-soal PISA. Soal literasi sains PISA yang terpilih dialihbahasakan, divalidasi oleh ahli, dilakukan uji coba, dan direvisi sampai didapatkan instrumen yang valid.

Data dianalisis dengan uji korelasi Spearman Rank berbantuan program SPSS. Rumus untuk menghitung koefisien korelasi adalah sebagai berikut (Sugiyono, 2009):

$r_{s}=1-\frac{6 \Sigma b i^{2}}{n\left(n^{2}-1\right)}$

Keterangan:

$\mathrm{r}_{\mathrm{s}}$ : koefisien korelasi Spearman Rank

$b_{i}$ : selisih ranking $X_{i}$ dengan $Y_{i}$

Nilai koefisien korelasi yang diperoleh diinterpretasikan menurut Tabel 1 (Sugiono, 2009). Kriteria pengujian yang digunakan dalam analisis korelasi dengan alpha 5\% yaitu ada hubungan signifikan antara kedua variabel jika signifikansinya $<0,05$, dan tidak hubungan jika signifikansinya $>0,05$.

Tabel 1. Interpretasi hubungan menurut koefisien korelasi

\begin{tabular}{ll}
\hline $\begin{array}{l}\text { Koefisien } \\
\text { Korelasi }\end{array}$ & Interpretasi \\
\hline $0,000-0,199$ & Sangat Lemah \\
$0,200-0,399$ & Lemah \\
\hline
\end{tabular}




\begin{tabular}{ll}
\hline $0,400-0,599$ & Cukup Kuat \\
$0,600-0,799$ & Kuat \\
$0,800-1,000$ & Sangat Kuat \\
\hline
\end{tabular}

\section{HASIL DAN PEMBAHASAN}

Sebelum uji korelasi pemahaman konsep dasar kimia dan kemampuan literasi sains dilakukan, kenormalan dan kelinearan data diuji terlebih dahulu untuk mengetahui terpenuhinya prasyarat data berdistribusi normal dan linear pada uji statistik parametrik.

Kenormalan distribusi data ditentukan dengan uji KolmogorovSmirnov pada program SPSS. Tabel 2 meringkaskan hasil uji normalitas data pemahaman konsep dasar kimia dan kemampuan literasi sains dari uji Kolmogorof-Smirnov. Berdasarkan uji normalitas, data pemahaman konsep dasar kimia, signifikansinya 0,004 atau dibawah 0,05 sehingga diartikan data pemahaman konsep dasar kimia tidak berdistribusi normal. Sementara itu, data kemampuan literasi sains signifikansinya 0,023 atau dibawah dari 0,05 sehingga diartikan bahwa data pemahaman konsep dasar kimia juga tidak berdistribusi normal.

Ringkasan hasil uji kelinearan data pemahaman konsep dasar kimia dan kemampuan literasi sains pada program SPSS digambarkan dalam tabel 3. Berdasarkan uji linearitas, tingkat signifikansinya 0,083 atau diatas 0,05 sehingga diinterpretasi hubungan kemampuan mengidentifikasi isu ilmiah dan kemampuan menggunakan bukti ilmiah bersifat linear.

Karena syarat kenormalan data pada uji statistik parametrik tidak terpenuhi, analisis korelasi menggunakan uji korelasi Spearman Rank pada program SPSS untuk menunjukkan hubungan kedua variabel.

Tabel 4 meringkaskan hasil uji korelasi Spearman Rank antara literasi sains dan pemahaman konsep dasar kimia. Dari tabel 4, hasil uji korelasi pemahaman konsep dasar kimia dan kemampuan literasi sains memiliki koefisien korelasi Spearman Rank yaitu 0,534 atau lebih besar dari $r_{s}$ tabel $(0,197)$. Sementara itu, signifikansinya 0,000 atau dibawah 0,05 sehingga diartikan adanya hubungan yang signifikan antara pemahaman konsep dasar kimia dengan kemampuan literasi sains. Koefisien korelasi diantara variabel pemahaman konsep dasar kimia dan variabel kemampuan literasi sains sebesar 0,534, dengan kata lain kedua variabel berkorelasi cukup kuat.

Tabel 3. Hasil Uji Linearitas

\begin{tabular}{ll}
\hline P-Value/Sig. & Kesimpulan \\
\hline 0.083 & Linear \\
\hline
\end{tabular}


Tabel 2. Hasil Uji Normalitas

\begin{tabular}{llll} 
& Pemahaman Konsep Dasar Kimia & $\begin{array}{l}\text { Kemampuan } \\
\text { Sains }\end{array}$ & Literasi \\
\hline $\begin{array}{l}\text { P-Value/Sig. } \\
\text { Kesimpulan }\end{array}$ & 0.004 & Tidak normal & 0.023 \\
\end{tabular}

Tabel 4. Hasil Uji Korelasi Spearman Rank

\begin{tabular}{llll}
\hline P-Value/Sign. & $\mathrm{r}_{\text {s hitung }}$ & $\mathrm{r}_{\text {stabel }}$ & Kesimpulan \\
\hline 0.000 & 0.534 & 0.197 & Berkorelasi \\
\hline
\end{tabular}

Korelasi positif yang cukup kuat dan signifikan antara variabel pemahaman konsep dasar kimia dan variabel menguatkan hasil studi TIMSS dan PISA. Studi TIMSS lebih pada penguasaan konten kimia, sedangkan PISA pada pengaplikasian pengetahuan tersebut (Shwartz et al., 2006). Jika mahasiswa mampu menghubungkan pengetahuan praktis pada pemahaman mereka tentang konsep dasar sains, literasi sains akan tercapai. Belajar akan bermakna jika ada keterhubungan suatu informasi terhadap pengetahuan sebelumnya (Dahar, 2013).

\section{KESIMPULAN}

Hasil penelitian menemukan adanya hubungan yang signifikan antara pemahaman konsep dasar kimia dengan kemampuan literasi sains. Selain itu, koefisien korelasi menunjukkan kedua variabel memilki tingkat hubungan yang cukup kuat. Semakin tinggi pemahaman konsep dasar kimia, kemampuan literasi ini, penting bagi pendidik untuk menguatkan pemahaman konsep dasar kimia dalam rangka meningkatkan penguasaan literasi sains. Selain itu, diperlukan riset lanjutan dalam menemukan faktor lain yang berpengaruh lebih kuat pada kemampuan literasi sains.

\section{DAFTAR PUSTAKA}

Balitbang Depdiknas. (2007). Ringkasan Studi PISA 2006. Jakarta: Depdiknas.

Cidgemoglu, C., Arslan, H.O., \& Cam, A. (2017). Argumentation to foster preservice science teachers' knowledge, competency, and attitude on the domains of chemical literacy of acids and bases. Chemistry Education Research and Practice, 18:288-303.

Dahar, R.W. (2011). Teori-Teori Belajar dan Pembelajaran. Jakarta: Erlangga.

Diana, S., Rachmatulloh, A., \& Rahmawati, E.S. (2015). Profil kemampuan literasi sains siswa SMA berdasarkan scientific literacy assessments (SLA), Prosiding Pada Seminar Nasional XII Pendidikan Biologi FKIP UNS 2015, h. 285-29. 
El Islami, R.A.Z., Nahadi, \& Permanasari, A. (2015). Hubungan literasi sains dan kepercayaan diri siswa pada konsep asam basa. Jurnal Penelitian dan Pembelajaran IPA, 1(1):16-25.

Fakhriyah, F., Masfuah, S., Roysa, M., Rusilowati, A., \& Rahayu, E.S. (2017). Student's science literacy in the aspect of content science?. Jurnal Pendidikan IPA Indonesia, 6(1):8187.

Holbrook, J. \& Rannikmae, M. (2009). The meaning of scientific literacy. International Journal of Environmental \& Science Education, 4(3):275-288.

OECD. (1999). Measuring student knowledge and skills: a new framework for assessment, PISA, OECD Publishing, Paris,https://www.oecd.org/educatio n/school/programmeforinternational studentassessmentpisa/33693997.pdf

OECD. (2013). PISA 2012 assessment and analytical framework: mathematics, reading, science, problem solving and financial literacy, PISA, OECD Publishing, Paris, http://dx.doi.org/10.1787/9789264190 $\underline{511-e n}$.

OECD. (2018). PISA 2015 results in focus, PISA, OECD Publishing, Paris, https://www.oecd.org/pisa/pisa2015-results-in-focus.pdf.

OECD. (2019). PISA 2018 Assessment and analytical framework, PISA, OECD Publishing, Paris, https://doi.org/10.1787/b25efab8-en

OECD. (2019). PISA 2018: insights and interpretations, PISA, OECD
Publishing, Paris, https://www.oecd.org/pisa/PISA\%20 2018\%20Insights\%20and\%20Interpr etations\%20FINAL\%20PDF.pdf.

Rahayuni, G. (2016). Hubungan keterampilan berpikir kritis dan literasi sains pada pembelajaran IPA terpadu dengan model PBM dan STM. Jurnal Penelitian dan Pembelajaran IPA, 2(2):131-146.

Rubini, B., Ardianto, D., Puspitasari, D., \& Permana, I. (2016). Identify scientific literacy from the science teachers perspective. Jurnal Pendidikan IPA Indonesia, 5(2):299303.

Rusdi, A., Sipahutar, H., \& Syarifuddin. (2017). Hubungan kemampuan berpikir kreatif dan sikap terhadap sains dengan literasi sains pada siswa kelas XI IPA MAN. Jurnal Pendidikan Biologi, 7(1):72-80.

Shwartz, Y., Bez-Zvi, R., \& Hofstein, A. (2006). The use of scientific literacy taxonomy for assessing the development of chemical literacy among high-school students. Chemistry Education Research and Practice, 7(4):203-225.

Sugiyono. (2009). Statistik untuk penelitian. Bandung: PT. Alfabeta.

Sujana, A., Permanasari, A., Sopandi, W., \& Mudzakir, A. (2014). Literasi kimia mahasiswa PGSD dan guru IPA sekolah dasar. Jurnal Pendidikan IPA Indonesia, 3(1):5-11.

Sukowati, D., Rusilowati, A., \& Sugianto. (2017). Analisis kemampuan literasi sains dan metakognitif peserta didik. Physics Communication, 1(1):16-22. 
e-ISSN: 2721-9038

p-ISSN: 2721-902X

Susiati, A., Adisyahputra, \& Miarsyah, M. (2018). Hubungan kemampuan membaca pemahaman dan kemampuan berpikir tingkat tinggi dengan kemampuan literasi sains guru biologi SMA. Biosfer: Jurnal Pendidikan Biologi, 11(1):1 